Perspective

\title{
The Post-COVID-19 Era: Interdisciplinary Demands of Contagion Surveillance Mass Spectrometry for Future Pandemics
}

\author{
Chaitanya Giri ${ }^{1,2}$, Henderson James Cleaves II ${ }^{2,3}\left(\mathbb{D}\right.$, Markus Meringer ${ }^{4}\left(\mathbb{D}\right.$ and Kuhan Chandru ${ }^{5, *(1)}$ \\ 1 Gateway House: Indian Council for Global Relations, 3rd Floor, Cecil Court, Colaba, Mumbai 400 005, India; \\ chaitanya.giri@elsi.jp \\ 2 Earth-Life Science Institute, Tokyo Institute of Technology, 2-12-1-IE-1 Ookayama, Meguro-ku, \\ Tokyo 152-8550, Japan; henderson.cleaves@gmail.com \\ 3 Blue Marble Space Institute of Science, Seattle, WA 98154, USA \\ 4 German Aerospace Center (DLR), Department of Atmospheric Processors, Münchener Straße 20, \\ 82234 Oberpfaffenhofen-Wessling, Germany; markus.meringer@dlr.de \\ 5 Space Science Center (ANGKASA), Institute of Climate Change, Level 3, Research Complex, \\ National University of Malaysia, UKM Bangi 43600, Malaysia \\ * Correspondence: kuhan@ukm.edu.my
}

check for updates

Citation: Giri, C.; Cleaves, H.J., II; Meringer, M.; Chandru, K. The Post-COVID-19 Era: Interdisciplinary Demands of Contagion Surveillance Mass Spectrometry for Future Pandemics. Sustainability 2021, 13, 7614. https://doi.org/10.3390/ su13147614

Academic Editor:

Christophe Waterlot

Received: 28 May 2021

Accepted: 4 July 2021

Published: 7 July 2021

Publisher's Note: MDPI stays neutral with regard to jurisdictional claims in published maps and institutional affiliations.

Copyright: (C) 2021 by the authors Licensee MDPI, Basel, Switzerland. This article is an open access article distributed under the terms and conditions of the Creative Commons Attribution (CC BY) license (https:/ / creativecommons.org/licenses/by/ $4.0 /)$.

\begin{abstract}
Mass spectrometry (MS) can become a potentially useful instrument type for aerosol, droplet and fomite (ADF) contagion surveillance in pandemic outbreaks, such as the ongoing SARS$\mathrm{CoV}-2$ pandemic. However, this will require development of detection protocols and purposing of instrumentation for in situ environmental contagion surveillance. These approaches include: (1) enhancing biomarker detection by pattern recognition and machine learning; (2) the need for investigating viral degradation induced by environmental factors; (3) representing viral molecular data with multidimensional data transforms, such as van Krevelen diagrams, that can be repurposed to detect viable viruses in environmental samples; and (4) absorbing engineering attributes for developing contagion surveillance MS from those used for astrobiology and chemical, biological, radiological, nuclear (CBRN) monitoring applications. Widespread deployment of such an MS-based contagion surveillance could help identify hot zones, create containment perimeters around them and assist in preventing the endemic-to-pandemic progression of contagious diseases.
\end{abstract}

Keywords: COVID-19; mass spectrometry; aerosols; droplets; fomite; surveillance; machine learning; van Krevelen diagram; viral degradation; astrobiology; CBRN; pandemic

\section{Introduction}

Viruses pervade Earth, but not much is known about their origin, evolution or precise role in global and local biogeochemical cycles [1-4]. It is estimated that there are $\sim 10^{31}$ viruslike particles on Earth, the vast majority of which are microbial symbionts [5]. The severe acute respiratory syndrome coronavirus-2 (SARS-CoV-2) is the causative agent of the novel coronavirus disease (COVID-19), which has led to tremendous global public health and socio-economic upheaval [6] since late 2019. As societies and economies attempt to revert to pre-pandemic normalcy, novel forms of contagion surveillance in heavily trafficked public spaces most associated with viral transmission could help avoid a pandemic relapse. Such surveillance requires rapid accurate identification of SARS-CoV-2-laden aerosol, droplet and fomite (ADF) samples [7-10]. However, to initiate a surveillance strategy for unambiguous detection of SARS-CoV-2 from ADF, knowledge of its infectivity and the design of portable mass spectrometers for virus detection in public spaces could be necessary.

The return to normal social and economic activity is challenged by what overwhelmingly appears to be the principal mode of transmission of SARS-CoV-2: airborne contagion 
via respiratory aerosols. The airborne journey, longevity and attachment to fomite surfaces (e.g., clothing, door handles, subway straps, rental cars, etc.) [11] of respiratory aerosols or droplets released by infected individuals has been monitored in ventilated indoor environments [12], clinics, cruise ships [13] and hospitals [8,10,14], and in pandemic hotspot regions through regular air sampling and biochemical analysis [15]. Respiratory aerosols smaller than $5 \mu \mathrm{m}[16,17]$ released by sneezing can attain a velocity of up to $100 \mathrm{~m} \mathrm{~s}^{-1}$, coughing can generate and proliferate the same types of aerosols with velocities of up to $50 \mathrm{~m} \mathrm{~s}^{-1}$, talking ones with velocities of $5 \mathrm{~m} \mathrm{~s}^{-1}$ and normal breathing ones with velocities of $1 \mathrm{~m} \mathrm{~s}^{-1}$ [18-20]. These aerosols can propagate throughout indoor environments [21-23], posing a threat to the public. Therefore, chemical surveillance of such microscopic aerosols and their attachment on fomites requires attention beyond standard RT-PCR analysis.

While RT-PCR analysis heavily depends on viral genomic materials to confirm the viral load in a human host, the non-genomic viral materials are equally significant for initiating infections [24,25]. Hence, even when an ADF sample gives a RT-PCR positive COVID-19 result based on SARS-CoV-2's genomic materials, it does not mean such samples are infectious if the non-genomic materials from the virions are degraded. Degradation caused by environmental factors (e.g., UV, temperature, etc.) may impede viral infectivity. Mass spectrometry (MS) may be especially effective for detecting viable virion-laden ADF samples due to its versatility, sensitivity and speed of analysis. MS can detect chemicals ranging from atoms to macromolecules (Figure 1) and may thereby be specific enough to detect select genomic and non-genomic viral components or whole virus particles. It may also be tailored for viral particle detection using miniaturized technologies inspired from other fields, such as astrobiology and chemical, biological, radiological and nuclear (CBRN) monitoring.

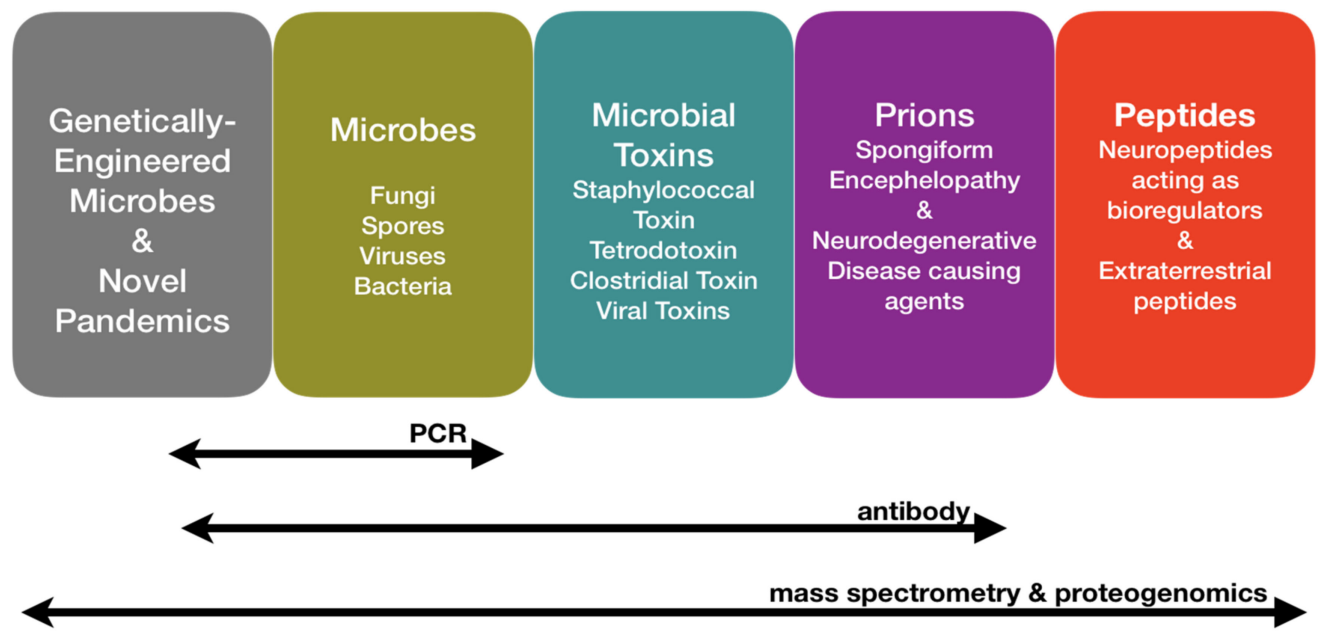

Figure 1. Range superiority of mass spectrometry in pathogen and macromolecule detection over polymerase chain reaction and antibody detection techniques. Adapted from Demirev, P. A. \& Fenselau, C. Mass spectrometry in biodefense. J. Mass Spectrom. 43, 1441-1457 (2008) (DOI:10.1002/jms.1474 (accessed on 12 September 2020)).

This perspective paper argues for the possible utility of MS in this role with the following highlighted points: (1) the need for machine learning in viral biomarker detection using MS; (2) the need for investigating viral degradation induced by environmental factors; (3) the potential use of multi-dimensional data analysis techniques, e.g., the van Krevelen diagram (vKd), in virus detection and evaluating their potential infectivity in ADF assessment; and (4) the concomitance between research and engineering of portable MS customized for epidemic or pandemic (e.g., detecting in situ infectious microbesviruses, fungi, bacteria) surveillance applications with those of astrobiology and homeland security applications. 


\section{Possible Pathogen Detection Using Benchtop MS with Machine Learning}

Pathogen detection using MS and machine learning has already been reported. Single particle mass spectrometry (SPMS) for real-time sensing of bioaerosols [26], when combined with automated data analysis enhanced by machine learning, allows for microbial detection [26]. For example, single particle laser desorption/ionization time-of-flight MS can detect pathogenic Mycobacterium tuberculosis (H37Ra) particles [27], based on a molecular marker at $\mathrm{m} / \mathrm{z} 421$, which is specific for this strain. However, there is a huge variation in the intensity at $m / z 421$ in a series of single-particle mass spectra of Mycobacterium tuberculosis, and approximately $34 \%$ of spectra are without a discernible signal at this mass position. The authors [27] followed a two-layered approach. They first used an unsupervised learning method to cluster mass spectra into groups indicating origin from similar particles. For this, they applied an algorithm [28] based on adaptive resonance theory (ART) in which MS signals were binned to integer $m / z$ units and the dot product on the resulting vectors was used to quantify the similarity of two spectra $[29,30]$. This is a standard method which is also fundamental for searching $70 \mathrm{eV}$ electron impact mass spectrometry (EI-MS) libraries [31]. The authors also examined variations and extensions of the dot product, e.g., by integrating intensity ratios into a so-called composite score, which turned out to perform even better in EI-MS library searches.

In a second step, microbial particles were further analyzed using a rule-based approach, which finally led to the biomarker of $m / z$ 421. This search can be automated by supervised learning methods in order to develop robust binary classifiers for microbial particles. In addition to intensities at integer $m / z$ units, further spectral features, such as intensity ratios and spectral shape descriptors, are used as independent (predictor) variables, whereas the dependent (predicted) variable is the binary yes/no answer. In a learning phase, such a classifier is trained using spectra of known class membership. After a successful learning phase, a classifier is generated which can then be applied to spectra of unknown class membership to obtain a predicted answer, together with a probability for correctness.

In the past such mass spectral classifiers have been built to predict structural properties from EI-MS using various machine learning methods, including $k$-nearest neighbor, linear discriminant analysis, neural networks [32,33], support vector machines and decision trees [34]. Decision tree learning extends what Tobias et al. [27] started to do manually, and typically leads to a hierarchically arranged set of rules achieving higher predictive accuracy than manually derived rules.

Though finding a molecular marker specific to a contagion (e.g., SARS-CoV-2) is challenging, other means in relation to COVID-19 diagnosis in human hosts have been demonstrated. These studies (e.g., [35,36]) have shown MS and machine learning protocols can identify distinctive spectral and peak features of peptidomes in human serum $[35,36]$ and metabolites in plasma samples [35,36] of COVID-19 patients (when compared with those of non-COVID-19 patients).

Nonetheless, given the present pandemic crisis, unambiguous molecular markers of SARS-CoV-2 virus or other pandemic causing contagions will be required for contagion monitoring applications in the future. However, for ADF virus detection, MS-based methods may be developed to explore unconventional '-omics' methods that allow analyses at high molecular mass ranges.

\section{Need for Viral Degradation Study Using MS to Understand the Range of Infectivity}

Human coronaviruses, including SARS-CoV and Middle East respiratory syndrome (MERS-CoV), are known to exist on inanimate surfaces for up to 9 days at room temperature [37]. But, a recent example of the Diamond Princess cruise ship outbreak, shows that after 17 days of discharging its positive COVID-19 passengers, the ship continued to have SARS-CoV-2's RNA particles in its air and fomites on its cabin surfaces (e.g., doorknobs, toilet seats, etc.) [13]. These samples were analyzed using RT-PCR, currently the gold standard to detect SARS-CoV-2 [38]. For this analysis, swab samples are usually pretreated by 
centrifugation, which is necessary to acquire viral RNA [39] that also discards non-genomic viral materials (e.g., capsid protein and membrane). However, these non-genomic materials are crucial virulence factors [24,25]. For example, a spike protein on SARS-CoV-2's exterior is essential for the virion's attachment to host cell angiotensin-converting enzyme 2 (ACE2) receptors for infection [40]. These spike proteins, as they are present on the outer surface of the virus, may experience early degradation in ADF sample environments.

Several reports have shown that virions can undergo structural degradation due to temperature fluctuations [41-43], UV irradiation [41,42,44], humidity [41-43] and desiccation [45]. Any of these environmental conditions, singularly or cumulatively, may reduce or eliminate the infectivity of SARS-CoV-2. Hence, the detection of infectivity on fomites in public places using RT-PCR is limited as it may give false positives. In contrast, MS can provide a measurement of the abundance of viral components (both genomic and nongenomic), whether they are infectious or not. Given that viability of the virion is associated with its intactness and that virions tend to degrade over time when not associated with hosts, this suggests that monitoring of potentially infection-associated signals could be a bellwether for the abundance of truly infectious viral entities. However, the effects of environmental degradation on viral infectivity must be determined.

We suggest a MS-based method (of fractionated and/or unfractionated samples) that can determine the effects of degradation on the infectivity of the virus by, (1) artificially exposing isolated strains of SARS-CoV-2 to prolonged environmental degradation simulations (e.g., UV exposure) with periodic sampling for MS analysis, and (2) concurrently cell culturing these periodically sampled virions. The first experiment will be useful to determine MS fragmentation patterns of the degraded viral strains that were sampled periodically. Next, the second experiment, i.e., cell culturing of these periodically degraded viral samples, can determine their continued infectivity [46]. Both experiments would inform the correlation of degraded samples' infectivity with molecular information derived from MS analysis.

\section{A Potential Way for Detecting Viral Infectivity in Aerosols, Droplets and Fomites Using MS with Van Krevelen Diagram}

SARS-CoV-2 degradation components may present unique mass spectral profiles [47,48], and infectivity may be estimable through examination of transforms of this data. Van Krevelen diagrams (vKd) may offer an example of the utility of such analysis. vKd has been used to explore polymer degradation in urban waste (e.g., [49]), of dissolved organic matter (DOM) in oceanographic samples (e.g., [50]) and, more recently, to study the impact of viral activity in marine bacterial communities in DOM [51]. The latter study demonstrates the utility of vKd to measure molecular changes within DOM, as a signature of viral infection in prokaryotic cells (Figure 2).

The DOM study [51] indicates that vKd could also be employed for plotting mass patterns of unfractionated SARS-CoV-2 samples, i.e., from purified (non-degraded) viral strain to increasingly degraded strains due to environmental factors (e.g., UV exposure, heat, etc.). A vKd for a SARS-CoV-2 can have an archetypal elemental ratio pattern demonstrating typical data point pattern of lipids, proteins, genomic molecules and other biomolecules, as shown in Figure 2B. This pattern is expected to change with the prior environmental degradation (Section 3) of the virions (e.g., [52,53]). When these degraded virions are allowed to infect cell cultures in order to determine the extent of infection, regions of data points on the vKd can be labelled to determine a "spectrum of infectivity". This spectrum can possibly be deemed as a standard reference plot showing elemental ratio patterns typical for various extents of infectivity. This standard plot can prove to be useful when compared with the MS measurements of virus-laden ADF samples collected from public spaces. Such a protocol can help determine the possible threat of ADF-tohuman transmission. 
A
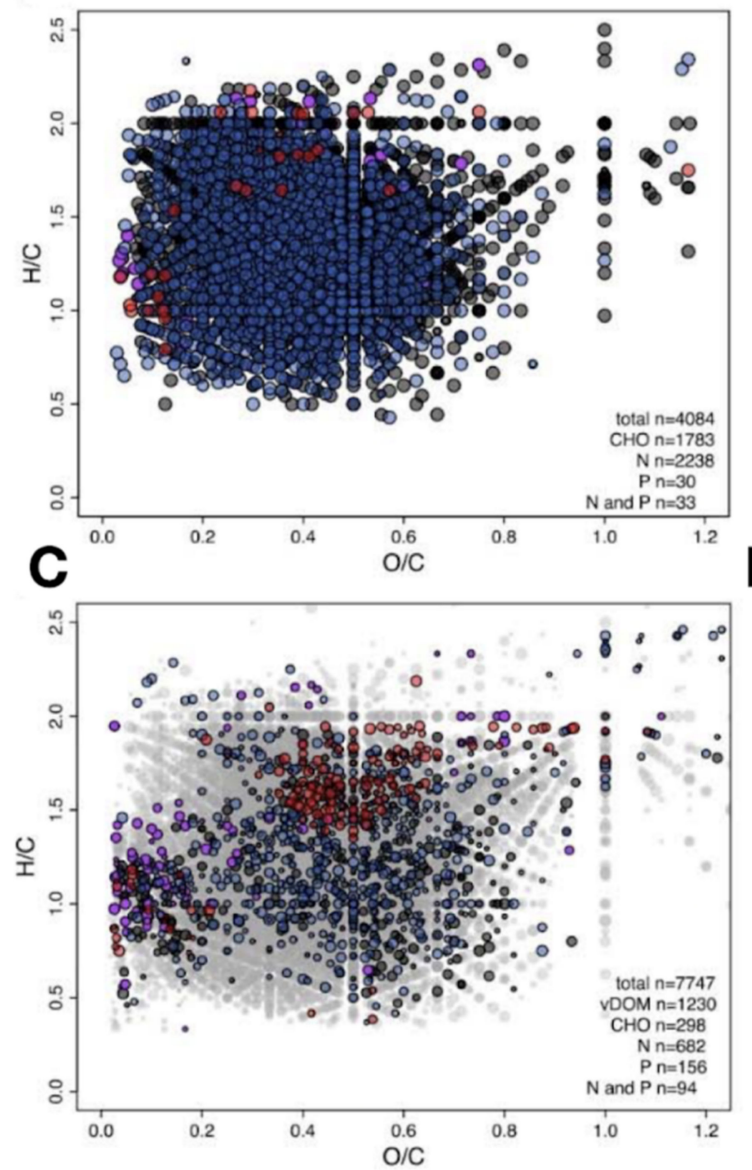

B

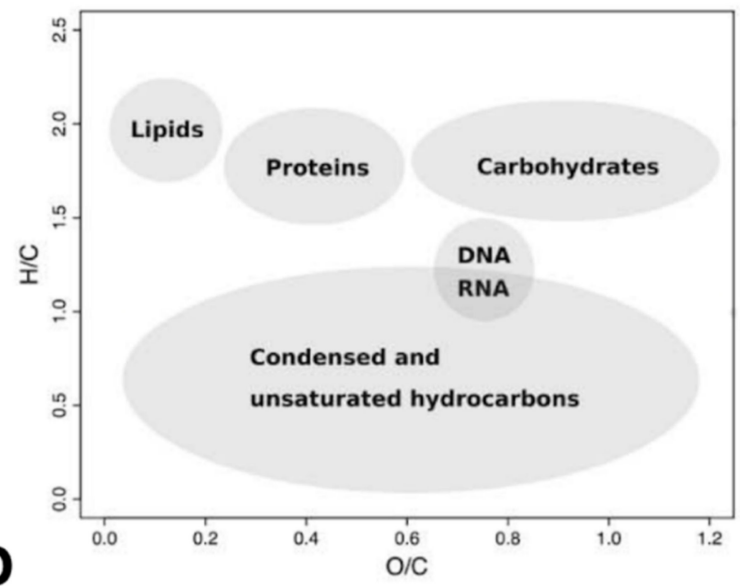

Abundance $01 \mathrm{O}_{5} \mathrm{O}_{10}$

DOM type

O Bulk DOM

$O$ vDOM

$\mathrm{O} N$

$\mathrm{O}$ and $\mathrm{P}$

Figure 2. This figure shows how vKd was utilized to represent changes in DOM. A prophage infection was introduced to a sampled DOM. Each data point represents one molecular formula, color-coded according to the $\mathrm{N}$ (nitrogen)- and $\mathrm{P}$ (phosphate)-content and locations of typical biochemical compound classes. (A) is showing the detected DOM molecular formula of the mitomycin-C treated slurry of a $20 \mathrm{~cm}$-below-sea-floor incubation sample according to the $\mathrm{H} / \mathrm{C}$ and $\mathrm{O} / \mathrm{C}$ ratios (vKd), where each data point represents a molecular formula. (B) is showing the regions of general biomolecular classes in a vKd diagram. (C) is the vKd showing changes in molecular compounds of the virus-mediated cell lysis of the DOM (vDOM) on day 6, and (D) is showing the residual DOM compounds at the end of the experiment on day 55. Note that, although this diagram shows the changes of DOM when exposed to the virus, similar methods can be applied for studying viral degradation patterns that may be useful for detecting infectivity in environmental fomites (see main text for more detailed explanation). Modified from Heinrichs, Mara E., Dennis A. Tebbe, Bernd Wemheuer, Juta Niggemann, and Bert Engelen. 2020. "Impact of Viral Lysis on the Composition of Bacterial Communities and Dissolved Organic Matter in Deep-Sea Sediments." Viruses 12 (9). https:/ / doi.org/10.3390/v12090922 [51]. Reprinted under creative common license.

However, such vKd-based crossplots are not without inherent technical limitations of MS instrumentation that require prompt attention. Firstly, vKd plots demand high resolution MS, such as a quadrupole mass spectrometer, even for the monitoring purposes to be compared with the reference $v K d$. These limitations can be overcome by isolating and amplifying virions collected from the ADF in cell culture, though isolation of virus-laden fomite samples was reported to be unsuccessful in recent work examining the Diamond Princess cruise ship [39] and PCR-positive air samples from medical facilities in China [54]. The failure of infectious virus particle isolation in these two studies indicates our lack of understanding of the viability of SARS-CoV-2 in ADF. We suspect that sampled viral-laden ADF may have undergone degradation, thus impeding their infectivity on cell cultures. Further study, as recommended in this publication and other studies [54], is required to understand how long viruses remain infectiously viable in ADF. 
Secondly, the MS capability of vKd-based methods would require sample viral loads high enough to yield detectable signals well above the background created by other biological matter [55]. This problem would require development of specific MS engineering or protocols to differentiate viral signals from background biological signals that demand strong machine learning protocols in place. Although it may reduce the sample throughout, sample preparation before MS analysis (e.g., chromatography following derivatization) may enhance detectability.

Finally, the central idea behind such surveillance is to create containment zones to reduce or prevent ADF-mediated transmission. This, however, requires in situ detection of contagions, which is not possible with the current high resolution MSs, which are mostly table-top or laboratory-based, and their analyses are time consuming. Generally, portability and miniaturization limit MS resolving power. The two well-known compromises have been the decrease in detector sensitivity and low $m / z$ accuracy. The health and economic impact of the COVID-19 pandemic and the need for virus-laden ADF surveillance in public spaces will hopefully provide some motivation to overcome these instrumentation limitations. Such measures, however, require prompt investments in the R\&D of high resolution and portable MS, including those that can do a vKd-like analyses, currently only possible with large and laboratory-based MS, being made. Such next-generation MS instruments could greatly help mitigate future pandemics.

\section{Sharing Engineering Attributes of MS used in Astrobiology and CBRN Monitoring with Future MS for In Situ Contagion-Laden ADF Surveillance}

The study of biomolecular degradation (e.g., [56-58]) in situ sampling and MS-based measurements (e.g., [59-63]) is a common topic in astrobiology, a transdisciplinary scientific pursuit to unravel the origins and potential distribution of life in the universe [64]. Astrobiology-driven planetary exploration is among the very few science domains that drives the R\&D of portable, miniature and tailor-made MS that can operate via remote or autonomous intervention without the need for direct human handling and operations. These include: the Sample Analysis at Mars (SAM) analytical suite, consisting of a quadrupole MS, and which is an important payload on the NASA Mars Science Laboratory rover [59,65]; the Cometary Sampling and Composition (COSAC) experiment on the Philae Lander of European Space Agency's (ESA) Rosetta Mission to comet 67P/ChuryumovGerasimenko, which consisted of a time-of-flight mass spectrometer [60,66]; and the Neutral Mass Spectrometer payload on ESA's Cassini-Huygens mission to Titan $[63,67,68]$. These MSs deployed for organic molecule or biosignature detection on extra-terrestrial surfaces have been able to identify prebiotic molecules and biomolecules from solid and volatile samples (e.g., $[63,69])$.

Coming back to Earth, MS have also been utilized for chemical, biological, radiological and nuclear (CBRN) monitoring on airports, sensitive government buildings, terror attack sites and warzones [70]. For example, the terror threats in the past, such as the nerve agent 'sarin' attack of 1995 in the Tokyo subway system, the distribution of anthrax spores in letters mailed in the U.S. in 2001, the notorious 'shoe bomber' incident in 2001 and the discovery of the biological toxin ricin in the U.S. Senate Office Building in 2004 [71], all prompted numerous security agencies around the world to develop monitoring protocols using vehicle-mounted and human-portable MS for in-situ detection. Effective ADF surveillance protocols for SARS-CoV-2-laden environments can have significant similarities with CBRN surveillance protocols as well.

Currently, there exist many commercial portable MS instruments which have been successfully used for in situ detection of marine microplastics and bulk forensic evidence of adulterated pharmaceuticals, and more recently for characterizing archeological artifacts (e.g., [72-74]). However, the MS instruments exclusively used for astrobiology and CBRN applications come closest to providing the MS features that would be needed for surveillance of contagion-laden ADF. This is because these types of MS can work autonomously on mobile or stationary platforms. They can sample their target analytes from the environment using continuous real-time "sniffing" measurement modes without need for extensive 
sample preparation. All of these attributes help speed the sampling process, allowing them to function as real-time monitoring devices.

Table 1 enumerates a few similarities between the technical specifications and engineering of MS instruments used for detecting infectious microbial contagion (viral, bacterial, fungal) detection in ADF and those used for astrobiology applications. These similarities include portability, miniaturization and autonomous sampling without human intervention. Some upcoming astrobiology-oriented MS instruments are expected to have a detection range of 100 to 1000 daltons [75,76]. In a scenario where infectious microbe detecting MS are developed concomitantly with astrobiology-oriented MS, a detection range of 100 mega-daltons to 1 giga-daltons could be aimed for.

Table 1. Concomitance of technical specifications of mass spectrometry for astrobiological and fomite surveillance applications.

\begin{tabular}{cc}
\hline $\begin{array}{c}\text { Portable Mass Spectrometer for Astrobiology } \\
\text { Applications }\end{array}$ & $\begin{array}{c}\text { Portable Mass Spectrometer for Contagion } \\
\text { Surveillance Applications }\end{array}$ \\
\hline $\begin{array}{c}\text { High resolution and mass/charge range for intact } \\
\text { biosignature detection (10-1000 daltons) (e.g., amino } \\
\text { acids, nucleotides, nucleobases etc.) }\end{array}$ & $\begin{array}{c}\text { High resolution and mass / charge range for intact } \\
\text { microbial signature detection (100 megadaltons-1 } \\
\text { giga-daltons) (e.g., lipid, RNA and proteins) }\end{array}$ \\
\hline Low payload mass for space payload needs & $\begin{array}{c}\text { Low payload mass for hand-held devices aerial } \\
\text { drone and autonomous ground vehicles }\end{array}$ \\
\hline $\begin{array}{c}\text { Low energy consumption with provisions for energy } \\
\text { storage backups }\end{array}$ & $\begin{array}{c}\text { Low energy consumption with provisions for } \\
\text { intermittent charging and plug-in options }\end{array}$ \\
\hline $\begin{array}{c}\text { Miniaturization of 2-4 GHz magnets (ion/electron } \\
\text { cyclotron) to match low payload requirements }\end{array}$ & $\begin{array}{c}\text { Miniaturization of 2-4 GHz magnets (ion/electron } \\
\text { cyclotron) to match with ergonomics and portability } \\
\text { requirements }\end{array}$ \\
\hline $\begin{array}{c}\text { Use of nano-mechanical resonators /aerodynamic } \\
\text { lenses for providing greater m/z resolution and } \\
\text { higher signal-to-noise ratio }\end{array}$ & $\begin{array}{c}\text { Use of nano-mechanical resonators/aerodynamic } \\
\text { lenses for greater resolution along with sample } \\
\text { nebulization }\end{array}$ \\
\hline $\begin{array}{c}\text { Ability to detect biosignature molecules in } \\
\text { atmospheric aerosols, geological rocks, regolith, } \\
\text { brine and clays, and liquid samples }\end{array}$ & $\begin{array}{c}\text { Ability to detect infectious microbial signatures and } \\
\text { estimate contagion infectivity in bioaerosols and } \\
\text { fomites in closed or public spaces }\end{array}$ \\
\hline
\end{tabular}

Since the advent of the COVID-19 pandemic, scientists have suggested the potential use of MS for breath analyses as a diagnostic measure [48,77,78], with some demonstrated preliminary results $[79,80]$. The technical suggestions they offer focus on simple sampling of breath in tubes, and later introducing the samples into table-top MS. However, we suggest the possibility of using the engineering attributes of portable and miniature MSs typically known from astrobiology and CBRN applications for further development of MS instruments that can directly sample infectious microbial contagion in ADFs without human intervention (Figure 3). This will require some technological innovation, but the use of MS for infectious microbial detection applications with attributes of proven astrobiologyoriented MS could, with some effort, hopefully be designed and deployed before the next pandemic outbreak. 


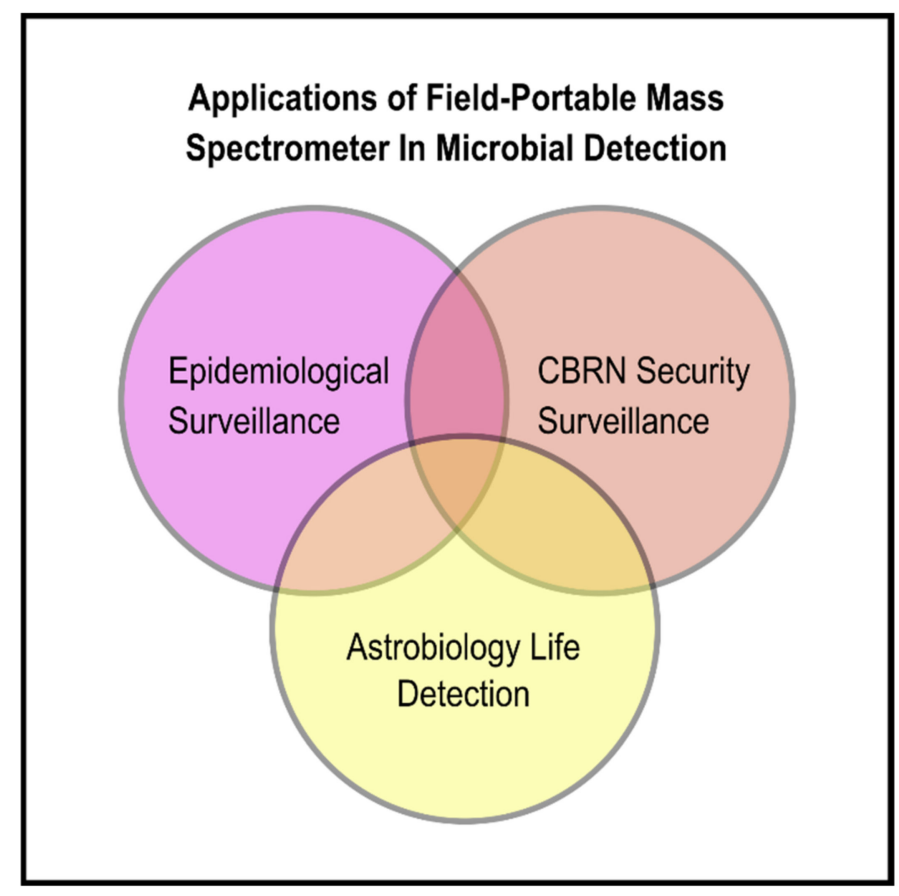

Figure 3. Multiple concomitant applications of field-portable microbial detection mass spectrometers. R\&D and engineering of MS for epidemiological contagion surveillance can take cues from portable MS used for astrobiology life detection and hazardous or weaponized chemical, biological, radiological and nuclear (CBRN) materials detection.

\section{Conclusions}

Many countries are attempting to find technical solutions to overcome the adverse impact of mass scale containment and economic lockdowns caused by the COVID-19 pandemic. There is particular interest in managing ADF transmission of the disease in various high human traffic environments such as airports, aircraft, offices and mass transit conveyances. ADF transmission can potentially be monitored using present day MS methods and instrumentation, and further engineered taking lessons from other fields.

Though not without its own challenges, the utility of incorporating machine learning with MS to determine potential viral molecular markers, viral degradation experiments and $\mathrm{vKd}$ represent some of the quickest possible ways to detect viable SARS-CoV-2 virions in ADF samples using conventional MS methods and instruments.

Concurrently, considering the global impact of the present COVID-19 pandemic, the demand for prompt investments into the R\&D of portable and high resolution MS for in situ monitoring of contagions in the environment is necessary. Design and engineering inspirations can be borrowed from mass spectrometers developed for astrobiology purposes and CBRN surveillance. The market demand for such MS instruments should produce the return on investment for the required R\&D and help make the manufacturing and per unit pricing cost-effective, in turn helping make such MS instruments more easily deployable in the long run. The deployment of such MS can also help curb the impact of future pandemics by enabling surveillance and quick detection of viral contagion-laden $\mathrm{ADF}$, especially in public places.

Author Contributions: C.G. and K.C. initiated the idea and outlined the manuscript, and together with H.J.C.II and M.M., wrote the manuscript. All authors have read and agreed to the published version of the manuscript.

Funding: This research received no specific grant. The article processing fee was supported by GP-2019-K022639 provided by the National University of Malaysia.

Institutional Review Board Statement: Not applicable. 
Informed Consent Statement: Not applicable.

Data Availability Statement: Not applicable.

Acknowledgments: The authors would like to thank the John Templeton Foundation and the EarthLife Science Institute (ELSI), Tokyo, for bringing all the authors together in one place from 2014-2017. We are also grateful to the following people for their initial discussion in regards to this manuscript: Mohd Shahrul Mohd Nadzir (National University of Malaysia) and Denise Kölbl (University of Vienna, Austria).

Conflicts of Interest: The authors declare no conflict of interest.

\section{References}

1. Durzyńska, J.; Goździcka-Józefiak, A. Viruses and Cells Intertwined since the Dawn of Evolution. Virol. J. 2015, 12, 169. [CrossRef]

2. Hegde, N.R.; Maddur, M.S.; Kaveri, S.V.; Bayry, J. Reasons to Include Viruses in the Tree of Life. Nat. Rev. Microbiol. $2009,7,615$. [CrossRef]

3. Moreira, D.; López-García, P. Ten Reasons to Exclude Viruses from the Tree of Life. Nat. Rev. Microbiol. 2009, 7, 306-311. [CrossRef]

4. Sorensen, G. The Role of the Virus-Phytoplankton System in Marine Biogeochemical Cycling: Possible Impacts of Climate Change; Univerity of Plymouth: Plymouth, UK, 2009.

5. Rohwer, F.; Prangishvili, D.; Lindell, D. Roles of Viruses in the Environment. Environ. Microbiol. 2009, 11, 2771-2774. [CrossRef]

6. WHO Announces COVID-19 Outbreak a Pandemic. 2020. Available online: https://www.euro.who.int/en/health-topics/ health-emergencies/coronavirus-covid-19/news/news/2020/3/who-announces-covid-19-outbreak-a-pandemic (accessed on 12 September 2020).

7. Al Huraimel, K.; Alhosani, M.; Kunhabdulla, S.; Stietiya, M.H. SARS-CoV-2 in the Environment: Modes of Transmission, Early Detection and Potential Role of Pollutions. Sci. Total Environ. 2020, 744, 140946. [CrossRef]

8. Liu, Y.; Ning, Z.; Chen, Y.; Guo, M.; Liu, Y.; Gali, N.K.; Sun, L.; Duan, Y.; Cai, J.; Westerdahl, D.; et al. Aerodynamic Analysis of SARS-CoV-2 in Two Wuhan Hospitals. Nature 2020. [CrossRef] [PubMed]

9. Santarpia, J.L.; Rivera, D.N.; Herrera, V.; Morwitzer, M.J.; Creager, H.; Santarpia, G.W.; Crown, K.K.; Brett-Major, D.; Schnaubelt, E.; Broadhurst, M.J.; et al. Aerosol and surface contamination of SARS-CoV-2 observed in quarantine and isolation care. Sci. Rep. 2020, 10, 12732. [CrossRef] [PubMed]

10. Chia, P.Y.; Coleman, K.K.; Tan, Y.K.; Ong, S.W.X.; Gum, M.; Lau, S.K.; Lim, X.F.; Lim, A.S.; Sutjipto, S.; Lee, P.H.; et al. Detection of Air and Surface Contamination by SARS-CoV-2 in Hospital Rooms of Infected Patients. Nat. Commun. 2020, 11, 2800. [CrossRef]

11. Aydogdu, M.O.; Altun, E.; Chung, E.; Ren, G.; Homer-Vanniasinkam, S.; Chen, B.; Edirisinghe, M. Surface Interactions and Viability of Coronaviruses. J. R. Soc. Interface 2021, 18, 20200798. [CrossRef] [PubMed]

12. Huang, C.; Wang, Y.; Li, X.; Ren, L.; Zhao, J.; Hu, Y.; Zhang, L.; Fan, G.; Xu, J.; Gu, X.; et al. Clinical Features of Patients Infected with 2019 Novel Coronavirus in Wuhan, China. Lancet 2020, 395, 497-506. [CrossRef]

13. Moriarty, L.F.; Plucinski, M.M.; Marston, B.J.; Kurbatova, E.V.; Knust, B.; Murray, E.L.; Pesik, N.; Rose, D.; Fitter, D.; Kobayashi, M.; et al. Public Health Responses to COVID-19 Outbreaks on Cruise Ships-Worldwide, February-March 2020. MMWR Morb. Mortal. Wkly. Rep. 2020, 69, 347-352. [CrossRef]

14. Nor, N.S.; Yip, C.W.; Ibrahim, N.; Jaafar, M.H.; Rashid, Z.Z.; Mustafa, N.; Hamid, H.H.A.; Chandru, K.; Latif, M.T.; Saw, P.E.; et al. Particulate Matter (PM2.5) as a Potential SARS-CoV-2 Carrier. Sci. Rep. 2021, 11, 2508. [CrossRef]

15. Van Doremalen, N.; Bushmaker, T.; Morris, D.H.; Holbrook, M.G.; Gamble, A.; Williamson, B.N.; Tamin, A.; Harcourt, J.L.; Thornburg, N.J.; Gerber, S.I.; et al. Aerosol and Surface Stability of SARS-CoV-2 as Compared with SARS-CoV-1. N. Engl. J. Med. 2020, 382, 1564-1567. [CrossRef] [PubMed]

16. Tellier, R.; Li, Y.; Cowling, B.J.; Tang, J.W. Recognition of Aerosol Transmission of Infectious Agents: A Commentary. BMC Infect. Dis. 2019, 19, 101. [CrossRef]

17. Wilson, N.M.; Norton, A.; Young, F.P.; Collins, D.W. Airborne Transmission of Severe Acute Respiratory Syndrome Coronavirus-2 to Healthcare Workers: A Narrative Review. Anaesthesia 2020. [CrossRef]

18. Wei, J.; Li, Y. Airborne Spread of Infectious Agents in the Indoor Environment. Am. J. Infect. Control. 2016, 44, S102-S108. [CrossRef]

19. Xie, X.; Li, Y.; Chwang, A.T.Y.; Ho, P.L.; Seto, W.H. How Far Droplets Can Move in Indoor Environments-Revisiting the Wells Evaporation-Falling Curve. Indoor Air 2007, 17, 211-225. [CrossRef]

20. Stadnytskyi, V.; Bax, C.E.; Bax, A.; Anfinrud, P. The Airborne Lifetime of Small Speech Droplets and Their Potential Importance in SARS-CoV-2 Transmission. Proc. Natl. Acad. Sci. USA 2020. [CrossRef] [PubMed]

21. Saw, L.H.; Leo, B.F.; Nor, N.S.M.; Yip, C.W.; Ibrahim, N.; Hamid, H.H.A.; Latif, M.T.; Lin, C.Y.; Nadzir, M.S.M. Modeling Aerosol Transmission of SARS-CoV-2 from Human-Exhaled Particles in a Hospital Ward. Environ. Sci. Pollut. Res. Int. 2021. [CrossRef] [PubMed]

22. Kennedy, M.; Lee, S.J.; Epstein, M. Modeling Aerosol Transmission of SARS-CoV-2 in Multi-Room Facility. J. Loss Prev. Process. Indust. 2021, 69, 104336. [CrossRef] 
23. Azimi, P.; Keshavarz, Z.; Cedeno Laurent, J.G.; Stephens, B.; Allen, J.G. Mechanistic Transmission Modeling of COVID-19 on the Diamond Princess Cruise Ship Demonstrates the Importance of Aerosol Transmission. Proc. Natl. Acad. Sci. USA 2021, 118. [CrossRef]

24. Shereen, M.A.; Khan, S.; Kazmi, A.; Bashir, N.; Siddique, R. COVID-19 Infection: Origin, Transmission, and Characteristics of Human Coronaviruses. J. Advert. Res. 2020, 24, 91-98. [CrossRef] [PubMed]

25. Lan, J.; Ge, J.; Yu, J.; Shan, S.; Zhou, H.; Fan, S.; Zhang, Q.; Shi, X.; Wang, Q.; Zhang, L.; et al. Structure of the SARS-CoV-2 Spike Receptor-Binding Domain Bound to the ACE2 Receptor. Nature 2020, 581, 215-220. [CrossRef] [PubMed]

26. Huffman, J.A.; Alex Huffman, J.; Perring, A.E.; Savage, N.J.; Clot, B.; Crouzy, B.; Tummon, F.; Shoshanim, O.; Damit, B.; Schneider, J.; et al. Real-Time Sensing of Bioaerosols: Review and Current Perspectives. Aerosol Sci. Technol. 2020, 54, 465-495. [CrossRef]

27. Tobias, H.J.; Schafer, M.P.; Pitesky, M.; Fergenson, D.P.; Horn, J.; Frank, M.; Gard, E.E. Bioaerosol Mass Spectrometry for Rapid Detection of Individual Airborne Mycobacterium Tuberculosis H37Ra Particles. Appl. Environ. Microbiol. 2005, 71, 6086-6095. [CrossRef] [PubMed]

28. Fergenson, D.P.; Pitesky, M.E.; Tobias, H.J.; Steele, P.T.; Czerwieniec, G.A.; Russell, S.C.; Lebrilla, C.B.; Horn, J.M.; Coffee, K.R.; Srivastava, A.; et al. Reagentless Detection and Classification of Individual Bioaerosol Particles in Seconds. Anal. Chem. 2004, 76, 373-378. [CrossRef]

29. Phares, D.J.; Rhoads, K.P.; Wexler, A.S.; Kane, D.B.; Johnston, M.V. Application of the ART-2a Algorithm to Laser Ablation Aerosol Mass Spectrometry of Particle Standards. Anal. Chem. 2001, 73, 2338-2344. [CrossRef]

30. Song, X.-H.; Hopke, P.K.; Fergenson, D.P.; Prather, K.A. Classification of Single Particles Analyzed by ATOFMS Using an Artificial Neural Network, ART-2A. Anal. Chem. 1999, 71, 860-865. [CrossRef]

31. Stein, S.E.; Scott, D.R. Optimization and Testing of Mass Spectral Library Search Algorithms for Compound Identification. J. Am. Soc. Mass Spectrom. 1994, 5, 859-866. [CrossRef]

32. Werther, W.; Lohninger, H.; Stancl, F.; Varmuza, K. Classification of Mass Spectra: A Comparison of Yes/No Classification Methods for the Recognition of Simple Structural Properties. Chemom. Intellig. Lab. Syst. 1994, 22, 63-76. [CrossRef]

33. Varmuza, K.; Werther, W. Mass Spectral Classifiers for Supporting Systematic Structure Elucidation. J. Chem. Inf. Comput. Sci. 1996, 36, 323-333. [CrossRef]

34. Kerber, A.; Laue, R.; Meringer, M.; Rücker, C.; Schymanski, E. Mathematical Chemistry and Chemoinformatics: Structure Generation, Elucidation and Quantitative Structure-Property Relationships; Walter de Gruyter: Berlin, Germany, 2013; ISBN 9783110254075.

35. Yan, L.; Yi, J.; Huang, C.; Zhang, J.; Fu, S.; Li, Z.; Lyu, Q.; Xu, Y.; Wang, K.; Yang, H.; et al. Rapid Detection of COVID-19 Using MALDI-TOF-Based Serum Peptidome Profiling. Anal. Chem. 2021, 93, 4782-4787. [CrossRef]

36. Delafiori, J.; Navarro, L.C.; Siciliano, R.F.; de Melo, G.C.; Busanello, E.N.B.; Nicolau, J.C.; Sales, G.M.; de Oliveira, A.N.; Val, F.F.A.; de Oliveira, D.N.; et al. Covid-19 Automated Diagnosis and Risk Assessment through Metabolomics and Machine Learning. Anal. Chem. 2021, 93, 2471-2479. [CrossRef]

37. Kampf, G.; Todt, D.; Pfaender, S.; Steinmann, E. Persistence of Coronaviruses on Inanimate Surfaces and Their Inactivation with Biocidal Agents. J. Hosp. Infect. 2020, 104, 246-251. [CrossRef]

38. Corman, V.M.; Landt, O.; Kaiser, M.; Molenkamp, R.; Meijer, A.; Chu, D.K.; Bleicker, T.; Brünink, S.; Schneider, J.; Schmidt, M.L.; et al. Detection of 2019 Novel Coronavirus (2019-nCoV) by Real-Time RT-PCR. Euro Surveill. 2020, 25. [CrossRef]

39. Yamagishi, T.; Ohnishi, M.; Matsunaga, N.; Kakimoto, K.; Kamiya, H.; Okamoto, K.; Suzuki, M.; Gu, Y.; Sakaguchi, M.; Tajima, T.; et al. Environmental Sampling for Severe Acute Respiratory Syndrome Coronavirus 2 during a COVID-19 Outbreak on the Diamond Princess Cruise Ship. J. Infect. Dis. 2020, 222, 1098-1102. [CrossRef] [PubMed]

40. Shang, J.; Wan, Y.; Luo, C.; Ye, G.; Geng, Q.; Auerbach, A.; Li, F. Cell Entry Mechanisms of SARS-CoV-2. Proc. Natl. Acad. Sci. USA 2020, 117, 11727-11734. [CrossRef] [PubMed]

41. Walker, C.M.; Ko, G. Effect of Ultraviolet Germicidal Irradiation on Viral Aerosols. Environ. Sci. Technol. 2007, 41, 5460-5465. [CrossRef]

42. Duan, S.-M.; Zhao, X.-S.; Wen, R.-F.; Huang, J.-J.; Pi, G.-H.; Zhang, S.-X.; Han, J.; Bi, S.-L.; Ruan, L.; Dong, X.-P.; et al. Stability of SARS Coronavirus in Human Specimens and Environment and Its Sensitivity to Heating and UV Irradiation. Biomed. Environ. Sci. 2003, 16, 246-255. [PubMed]

43. Casanova, L.M.; Jeon, S.; Rutala, W.A.; Weber, D.J.; Sobsey, M.D. Effects of Air Temperature and Relative Humidity on Coronavirus Survival on Surfaces. Appl. Environ. Microbiol. 2010, 76, 2712-2717. [CrossRef]

44. Garcia de Abajo, F.J.; Hernández, R.J.; Kaminer, I.; Meyerhans, A.; Rosell-Llompart, J.; Sanchez-Elsner, T. Back to Normal: An Old Physics Route to Reduce SARS-CoV-2 Transmission in Indoor Spaces. ACS Nano 2020, 14, 7704-7713. [CrossRef]

45. Abad, F.X.; Pintó, R.M.; Bosch, A. Survival of Enteric Viruses on Environmental Fomites. Appl. Environ. Microbiol. 1994, 60, 3704-3710. [CrossRef] [PubMed]

46. Casadevall, A. The Pathogenic Potential of a Microbe. mSphere 2017, 2. [CrossRef]

47. Overmyer, K.A.; Shishkova, E.; Miller, I.J.; Balnis, J.; Bernstein, M.N.; Peters-Clarke, T.M.; Meyer, J.G.; Quan, Q.; Muehlbauer, L.K.; Trujillo, E.A.; et al. Large-Scale Multi-Omic Analysis of COVID-19 Severity. Cell Syst. 2021, 12, 23-40.e7. [CrossRef] [PubMed]

48. Mahmud, I.; Garrett, T.J. Mass Spectrometry Techniques in Emerging Pathogens Studies: COVID-19 Perspectives. J. Am. Soc. Mass Spectrom. 2020, 31, 2013-2024. [CrossRef] [PubMed]

49. Chia, J.W.F.; Sawai, O.; Nunoura, T. Reaction Pathway of Poly(ethylene) Terephthalate Carbonization: Decomposition Behavior Based on Carbonized Product. Waste Manag. 2020, 108, 62-69. [CrossRef] 
50. Medeiros, P.M.; Seidel, M.; Powers, L.C.; Dittmar, T.; Hansell, D.A.; Miller, W.L. Dissolved Organic Matter Composition and Photochemical Transformations in the Northern North Pacific Ocean. Geophys. Res. Lett. 2015, 42, 863-870. [CrossRef]

51. Heinrichs, M.E.; Tebbe, D.A.; Wemheuer, B.; Niggemann, J.; Engelen, B. Impact of Viral Lysis on the Composition of Bacterial Communities and Dissolved Organic Matter in Deep-Sea Sediments. Viruses 2020, 12, 922. [CrossRef]

52. Miller, R.L.; Plagemann, P.G. Effect of Ultraviolet Light on Mengovirus: Formation of Uracil Dimers, Instability and Degradation of Capsid, and Covalent Linkage of Protein to Viral RNA. J. Virol. 1974, 13, 729-739. [CrossRef]

53. Lytle, C.D.; Sagripanti, J.-L. Predicted Inactivation of Viruses of Relevance to Biodefense by Solar Radiation. J. Virol. 2005, 79, 14244-14252. [CrossRef] [PubMed]

54. Ong, S.W.X.; Tan, Y.K.; Coleman, K.K.; Tan, B.H.; Leo, Y.-S.; Wang, D.L.; Ng, C.G.; Ng, O.-T.; Wong, M.S.Y.; Marimuthu, K. Lack of Viable Severe Acute Respiratory Coronavirus Virus 2 (SARS-CoV-2) among PCR-Positive Air Samples from Hospital Rooms and Community Isolation Facilities; Cambridge University Press: Cambridge, UK, 2021.

55. Rodríguez, R.A.; Pepper, I.L.; Gerba, C.P. Application of PCR-Based Methods to Assess the Infectivity of Enteric Viruses in Environmental Samples. Appl. Environ. Microbiol. 2009, 75, 297-307. [CrossRef] [PubMed]

56. Aubrey, A.D.; Cleaves, H.J.; Bada, J.L. The Role of Submarine Hydrothermal Systems in the Synthesis of Amino Acids. Orig. Life Evol. Biosph. 2009, 39, 91-108. [CrossRef] [PubMed]

57. Chandru, K.; Imai, E.; Kaneko, T.; Obayashi, Y.; Kobayashi, K. Survivability and Abiotic Reactions of Selected Amino Acids in Different Hydrothermal System Simulators. Orig. Life Evol. Biosph. 2013, 43, 99-108. [CrossRef] [PubMed]

58. Saladino, R.; Neri, V.; Crestini, C.; Costanzo, G.; Graciotti, M.; Di Mauro, E. Synthesis and Degradation of Nucleic Acid Components by Formamide and Iron Sulfur Minerals. J. Am. Chem. Soc. 2008, 130, 15512-15518. [CrossRef]

59. Johnson, P.V.; Hodyss, R.; Tang, K.; Brinckerhoff, W.B.; Smith, R.D. The Laser Ablation Ion Funnel: Sampling for in Situ Mass Spectrometry on Mars. Planet. Space Sci. 2011, 59, 387-393. [CrossRef]

60. Goesmann, F.; Rosenbauer, H.; Bredehöft, J.H.; Cabane, M.; Ehrenfreund, P.; Gautier, T.; Giri, C.; Krüger, H.; Le Roy, L.; MacDermott, A.J.; et al. COMETARY SCIENCE. Organic Compounds on Comet 67P/Churyumov-Gerasimenko Revealed by COSAC Mass Spectrometry. Science 2015, 349, aab0689. [CrossRef] [PubMed]

61. Briois, C.; Thissen, R.; Thirkell, L.; Aradj, K.; Bouabdellah, A.; Boukrara, A.; Carrasco, N.; Chalumeau, G.; Chapelon, O.; Colin, F.; et al. Orbitrap Mass Analyser for in Situ Characterisation of Planetary Environments: Performance Evaluation of a Laboratory Prototype. Planet. Space Sci. 2016, 131, 33-45. [CrossRef]

62. Goesmann, F.; Brinckerhoff, W.B.; Raulin, F.; Goetz, W.; Danell, R.M.; Getty, S.A.; Siljeström, S.; Mißbach, H.; Steininger, H.; Arevalo, R.D., Jr.; et al. The Mars Organic Molecule Analyzer (MOMA) Instrument: Characterization of Organic Material in Martian Sediments. Astrobiology 2017, 17, 655-685. [CrossRef] [PubMed]

63. Vazquez, T.; Vuppala, S.; Ayodeji, I.; Song, L.; Grimes, N.; Evans-Nguyen, T. IN SITU MASS SPECTROMETERS FOR APPLICATIONS IN SPACE. Mass Spectrom. Rev. 2020. [CrossRef] [PubMed]

64. National Academies of Sciences, Engineering, and Medicine; Division on Engineering and Physical Sciences; Space Studies Board; Committee on Astrobiology Science Strategy for the Search for Life in the Universe. An Astrobiology Strategy for the Search for Life in the Universe; National Academies Press: Washington, DC, USA, 2019; ISBN 9780309484169.

65. Mahaffy, P.R.; Webster, C.R.; Cabane, M.; Conrad, P.G.; Coll, P.; Atreya, S.K.; Arvey, R.; Barciniak, M.; Benna, M.; Bleacher, L.; et al. The Sample Analysis at Mars Investigation and Instrument Suite. Space Sci. Rev. 2012, 170, 401-478. [CrossRef]

66. Meringer, M.; Giri, C.; Cleaves, H.J. Fitting Cometary Sampling and Composition Mass Spectral Results Using Non-Negative Least Squares: Reducing Detection Ambiguity for In Situ Solar System Organic Compound Measurements. ACS Earth Space Chem. 2018, 2, 1256-1261. [CrossRef]

67. Waite, J.H., Jr.; Niemann, H.; Yelle, R.V.; Kasprzak, W.T.; Cravens, T.E.; Luhmann, J.G.; McNutt, R.L.; Ip, W.-H.; Gell, D.; De La Haye, V.; et al. Ion Neutral Mass Spectrometer Results from the First Flyby of Titan. Science 2005, 308, 982-986. [CrossRef]

68. Ali, A.; Sittler, E.C., Jr.; Chornay, D.; Rowe, B.R.; Puzzarini, C. Organic Chemistry in Titan' S Upper Atmosphere and Its Astrobiological Consequences: I. Views towards Cassini Plasma Spectrometer (CAPS) and Ion Neutral Mass Spectrometer (INMS) Experiments in Space. Planet. Space Sci. 2015, 109, 46-63. [CrossRef]

69. Janjic, A. The Need for Including Virus Detection Methods in Future Mars Missions. Astrobiology 2018, 18, 1611-1614. [CrossRef]

70. Demirev, P.A.; Fenselau, C. Mass Spectrometry in Biodefense. J. Mass Spectrom. 2008, 43, 1441-1457. [CrossRef] [PubMed]

71. Trapp, R. Living with Chemicals: How to Prevent Their Use for Hostile Purposes and Mitigate Chemical Risks. In Cyber and Chemical, Biological, Radiological, Nuclear, Explosives Challenges: Threats and Counter Efforts; Martellini, M., Malizia, A., Eds.; Springer International Publishing: Cham, Switzerland, 2017; pp. 357-383. ISBN 9783319621081.

72. Zhang, X.; Zhang, H.; Yu, K.; Li, N.; Liu, Y.; Liu, X.; Zhang, H.; Yang, B.; Wu, W.; Gao, J.; et al. Rapid Monitoring Approach for Microplastics Using Portable Pyrolysis-Mass Spectrometry. Anal. Chem. 2020, 92, 4656-4662. [CrossRef]

73. Fatigante, W.L.; Mukta, S.; Lawton, Z.E.; Bruno, A.M.; Traub, A.; Gasa, A.J.; Stelmack, A.R.; Wilson-Frank, C.R.; Mulligan, C.C. Filter Cone Spray Ionization Coupled to a Portable MS System: Application to On-Site Forensic Evidence and Environmental Sample Analysis. J. Am. Soc. Mass Spectrom. 2020, 31, 336-346. [CrossRef] [PubMed]

74. La Nasa, J.; Nardella, F.; Modugno, F.; Colombini, M.P.; Ribechini, E.; Degano, I. SIFT-Ing Archaeological Artifacts: Selected Ion Flow Tube-Mass Spectrometry as a New Tool in Archaeometry. Talanta 2020, 207, 120323. [CrossRef] 
75. Tulej, M.; Riedo, A.; Neuland, M.B.; Meyer, S.; Wurz, P.; Thomas, N.; Grimaudo, V.; Moreno-García, P.; Broekmann, P.; Neubeck, A.; et al. CAMAM: A Miniature Laser Ablation Ionisation Mass Spectrometer and Microscope-Camera System forIn SituInvestigation of the Composition and Morphology of Extraterrestrial Materials. Geostand. Geoanal. Res. 2014, 38, 441-466. [CrossRef]

76. Snyder, D.T.; Pulliam, C.J.; Ouyang, Z.; Cooks, R.G. Miniature and Fieldable Mass Spectrometers: Recent Advances. Anal. Chem. 2016, 88, 2-29. [CrossRef]

77. Walker, H.J.; Burrell, M.M. Could Breath Analysis by MS Could Be a Solution to Rapid, Non-Invasive Testing for COVID-19? Bioanalysis 2020, 12, 1213-1217. [CrossRef] [PubMed]

78. Gould, O.; Ratcliffe, N.; Król, E.; de Lacy Costello, B. Breath Analysis for Detection of Viral Infection, the Current Position of the Field. J. Breath Res. 2020, 14, 041001. [CrossRef] [PubMed]

79. Ruszkiewicz, D.M.; Sanders, D.; O’Brien, R.; Hempel, F.; Reed, M.J.; Riepe, A.C.; Bailie, K.; Brodrick, E.; Darnley, K.; Ellerkmann, R.; et al. Diagnosis of COVID-19 by Analysis of Breath with Gas Chromatography-Ion Mobility Spectrometry-A Feasibility Study. EClinicalMedicine 2020, 29, 100609. [CrossRef]

80. Cardozo, K.H.M.; Lebkuchen, A.; Okai, G.G.; Schuch, R.A.; Viana, L.G.; Olive, A.N.; Lazari, C.D.S.; Fraga, A.M.; Granato, C.F.H.; Pintão, M.C.T.; et al. Establishing a Mass Spectrometry-Based System for Rapid Detection of SARS-CoV-2 in Large Clinical Sample Cohorts. Nat. Commun. 2020, 11, 6201. [CrossRef] [PubMed] 